\title{
Screening and selection of growth-promoting bacteria for Dunaliella cultures
}

\author{
M. Le Chevanton ${ }^{a}$, M. Garnier ${ }^{a}{ }^{*}$, G. Bougaran $^{a}$, N. Schreiber ${ }^{a}$, E. Lukomska ${ }^{a}$, J.-B. Bérard ${ }^{a}$, \\ E. Fouilland ${ }^{b}$, O. Bernard ${ }^{\mathrm{c}}$, J.-P. Cadoret $^{\mathrm{a}}$
}

\author{
a Laboratoire de Physiologie et de Biotechnologie des Algues, IFREMER, rue de l'lle d'Yeu, 44300 NANTES, \\ France \\ b Laboratoire d'Ecologie des Systèmes Marins Côtiers, UMR 5119 ECOSYM (Université Montpellier 2, CNRS, \\ IRD, IFREMER, Université Montpellier 1), Station Méditerranéenne de l'Environnement Littoral, 2 rue des \\ chantiers, 34200 SETE, France \\ ${ }^{c}$ Biological Control of Artificial Ecosystem, INRIA, BP093, 06902 SOPHIA-ANTIPOLIS cedex, France \\ *: Corresponding author : Matthieu Garnier, tel.: + 33240374336 ; fax: + 33240374071 ; \\ email address : matthieu.garnier@ifremer.fr
}

\begin{abstract}
:
Previous studies have demonstrated that bacteria influence microalgal metabolism, suggesting that the selection and characterization of growth-promoting bacteria should offer a new strategy for improving industrial algal cultivation. In the present study, 48 cultivable bacteria were isolated from marine microalgae species and identified using 16S rRNA phylogenetic analysis. The recovered bacteria were found to be members of the $\alpha$ - and $y$-Proteobacteria, Cytophaga-FlavobacteriumBacteroides (CFB) and gram-positive monophyletic clusters. To address the effect of these bacteria on the growth of Dunaliella sp. individually, an experimental high-throughput tool was developed to simultaneously compare replicated associations. A two-step approach was used to monitor growth rate and biomass accumulation of Dunaliella sp. in mixed culture with bacteria, which proved the highthroughput device to be an efficient tool for the selection of growth-promoting bacteria. Depending on the bacterial strain involved, inhibitory effects were recorded for maximal microalgal growth rate, whereas inhibitory and stimulating effects were registered on microalgal biomass accumulation and nitrogen incorporation. Organic nitrogen remineralization by Alteromonas sp. SY007 and Muricauda sp. SY244 is discussed to explain the higher biomass and ammonium incorporation of Dunaliella sp. obtained under nitrogen-limited conditions. These bacteria could be considered as helpers for $\mathrm{N}$ accumulation in Dunaliella sp. cells.
\end{abstract}

Keywords: Microalgae ; Dunaliella ; Bacteria ; Interaction ; Bacterial diversity

Highlights We developed a high-throughput tool to evaluate microalgae-bacteria interactions We selected growth-promoting bacteria for Dunaliella sp. The growth promoting bacteria enhanced nitrogen incorporation in Dunaliella cultures.

Abbreviations : $\mu_{\max }$, maximal growth rate ;

$\Delta X_{\max }$, maximal biomass increase at stationary phase ;

$\mathrm{C}: \mathrm{N}$, carbon:nitrogen ratio ;

Chl a, chlorophyll a ;

RAPD, random amplification of polymorphic DNA 


\section{Introduction}

There is a diverse array of current and potential applications for microalgae, which include food, animal feed, healthcare, energy and phycoremediation [1-3]. The boom of microalgal value-adding over recent decades has drawn attention to the study of bacteria-microalgae interactions in applied algal cultivation [4,5]. Bacteria can compete with microalgae for the limited resources [6,7] or even produce toxic substances against microalgae [8], all of which can decrease culture yields. Axenic microalgae cultures appear to be too unrealistic and labour-intensive for large-scale cultivation, but the addition of selected probiotic bacteria may be beneficial to cultures of microalgae as a preventive action against an inhibiting bacterial population $[9,10]$. Such added bacteria may also increase microalgae growth rates, and thus enhance culture yields, through the synthesis of growth-promoting compounds [11-13] such as vitamins, or by improving nutrient supply through remineralization of organic nitrogen excreted by microalgae [14]. The strong influence that bacteria can have on maximal growth rate and cell density of different microalgae species was demonstrated by Liu et al. (2008) by the addition of a Bacillus strain to microalgae cultures [15]. Aside from growth, other aspects of microalgal metabolism may be affected by bacteria such as cell size, pigment and lipid content, and variety of fatty acids, observed in the association of Chlorella vulgaris cells with Azospirillum brasilense [16], for example. In addition, toxin production [17], extracellular secretions [18] and cell aggregation [19] are all parameters that may potentially be affected in microalgae grown in association with some heterotrophic prokaryotes.

New strategies for the production of biogas through anaerobic digestion lead to a high amount of ammonium. A coupling with the production of microalgae has been suggested as an effective way to use this huge quantities of nitrogen required for microalgae-based biofuel production [20]. The proposed process results in the recycling of nitrogen and flux of ammonium back to the microalgae culture. Additionally, the use of Dunaliella $s p$. has been proposed for carbon dioxide and ammonium remediation [21], biofuel production [22] and methane production [23]. Indeed, Dunaliella sp. exhibit ecological valence for major environmental factors such as irradiance, $\mathrm{pH}$, salinity and temperature: this makes them good candidates for large-scale cultivation [24] and means that they could be coupled to anaerobic digestion and nutrient recycling. However, to the best of our knowledge, the selection of growth-promoting bacteria has not been used, to date, as a method to increase the industrial production of Dunaliella sp..

In the present study, we focused on selecting bacteria that promote growth for Dunaliella sp. SAG 19.3 in a specific context : the coupling of anaerobic digestion to microalgae production. In particular, we tested the ability of bacteria to increase growth and nitrogen incorporation for this microalgae. Accordingly, ammonium-limiting conditions were used to evaluate the effects of bacteria. This study was also conducted without vitamin enrichment in order to test for bacteria ability to supply vitamins to microalgae. The first part of this research consisted of isolating and characterizing cultivable bacteria from various microalgal cultures for subsequent testing in association with Dunaliella sp. SAG 19.3. In a high-throughput experiment we first screened a large number of microalgae - bacteria associations for their effect on microalgae growth. Three selected bacteria strains with potential growth altering effects on Dunaliella $s p$ were further tested in a flask experiment. Results highlighted the growth altering effects on Dunaliella $s p$. SAG 19.3 and influence of these bacteria on nitrogen incorporation in microalgae. 


\section{Materials and methods}

\subsection{Algal strain, maintenance and purification}

Dunaliella sp. SAG 19.3 was obtained from the culture collection of algae at the University of Goettingen (SAG) Germany, and maintained at $20{ }^{\circ} \mathrm{C}$ under continuous light with daylight fluorescent tubes $\left(50 \mu \mathrm{mol}\right.$ photons $\left.\mathrm{m}^{-2} \mathrm{~s}^{-1}\right)$. Cultures were performed in sterile Erlenmeyer flasks filled with artificial seawater (ASW, salinity 35) [25] filtered at $0.22 \mu \mathrm{m}$ and enriched with modified Walne"s medium [26]. Ammonium was used as a nitrogen source (1.17 mM) and vitamins were omitted. The initial Dunaliella $s p$. culture obtained from the SAG collection will hereinafter be referred as the xenic culture.

To eliminate bacteria initially associated with Dunaliella sp. SAG 19.3 and to obtain axenic cultures, cells were harvested by centrifugation (500 g for $3 \mathrm{~min}$ at $20^{\circ} \mathrm{C}$ ) just before the stationary phase, then transferred to a fresh Erlenmeyer flask containing enriched ASW (as described above) and a specific mix of antibiotics based on Cho et al [27]: $1250 \mu \mathrm{g}$ ampicillin, $250 \mu \mathrm{g}$ gentamycin, $500 \mu \mathrm{g}$ kanamycin, and $2500 \mu \mathrm{g}$ neomycin were added per $\mathrm{mL}$ of culture. A first 7-day antibiotic treatment was conducted, followed by a 20-day batch culture without treatment. Cells were then washed with sterile seawater to eliminate remaining free bacteria and a second 7-day treatment was conducted. Absence of bacteria was verified by epifluorescence microscopy using SYBRGreen ${ }^{\circledR}$ I Stain (Lonza, USA) and by plating on Marine Agar (BD Difco ${ }^{\mathrm{TM}} 212185$, Becton Dickinson and Company, USA). Plates were incubated for 10 days at $20^{\circ} \mathrm{C}$ before observation.

\subsection{Bacterial collection from microalgae culture: isolation and $16 \mathrm{~S}$ rRNA analysis}

Bacteria were isolated from 19 marine monospecific microalgae cultres maintained in the laboratory. Microalgae were cultivated in sterilized seawater enriched with Walne"s medium at $20{ }^{\circ} \mathrm{C}$ under continuous light $\left(50 \mu \mathrm{mol}\right.$ photons $\left.\mathrm{m}^{-2} \mathrm{~s}^{-1}\right)$ and isolation was performed at the early stationary phase to select bacteria that grow well together with microalgae. Free living bacteria were isolated by plating xenic microalgae culture on Marine Agar (BD Difco ${ }^{\mathrm{TM}}$ 212185, Becton Dickinson and Company, USA) at $20^{\circ} \mathrm{C}$. Isolates were cultured in liquid Marine Broth (BD Difco ${ }^{\mathrm{TM}} 279110$, Becton Dickinson and Company, USA) and stored at -80 ${ }^{\circ} \mathrm{C}$ after addition of $5 \%$ Dimethyl sulfoxide (D 8779, Sigma-Aldrich, USA).

For each strain, nucleic acids were extracted by phenol/chloroform extraction followed by isopropanol precipitation [28]. Amplification of the bacterial 16S rRNA gene was performed using universal primers SAdir (5"-AGAGTTTGATCATGGCTCAGA-3") and S17 Rev (5'GTTACCTTGTTACGACTT-3") [29]. The PCR mixture (25 $\mu \mathrm{L})$ was composed of $100 \mathrm{ng}$ DNA, 50 pmol of each primer, $0.2 \mathrm{mM}$ of each dNTP, $1.5 \mathrm{mM}$ of $\mathrm{MgCl}_{2}$, $1 \times$ of $\mathrm{GoTaq}^{\mathrm{TM}}$ Buffer $\left(\mathrm{GoTaq}^{\mathrm{TM}} \mathrm{kit}\right.$, Promega, USA) and 1.25 units of Taq Polymerase (GoTaq ${ }^{\mathrm{TM}} \mathrm{kit}$, Promega, USA). Amplification was carried out on a thermocycler (MyCycler, BIO-RAD) according to the following procedure: $5 \mathrm{~min}$ at $94{ }^{\circ} \mathrm{C}$, then 35 cycles including $35 \mathrm{~s}$ at $94{ }^{\circ} \mathrm{C}, 1 \mathrm{~min}$ at $54{ }^{\circ} \mathrm{C}$ and $1 \mathrm{~min} 30 \mathrm{~s}$ at $72{ }^{\circ} \mathrm{C}$, and a final step of $7 \mathrm{~min}$ at $72{ }^{\circ} \mathrm{C}$. PCR products were checked on a $0.8 \%$ agarose electrophoresis gel.

The amplified lengths of DNA were then sequenced at "Plateforme Biogenouest" (Roscoff, France, http://www.sb-roscoff.fr/plateformes-techniques/genomique-sbr.html) on an $A B I$ Prism $^{\mathrm{TM}} 3100 \mathrm{GA}$, using BigDye ${ }^{\circledR}$ Terminator v3.1 chemistry (Applied Biosystems) and the SAdir primer. Taxonomic classification was performed online with Ribosomal Database Project Classifier Version 2.5 software, hierarchical taxa assignment beeing based on RDP naïve Bayesian rRNA Classifier and 95\% confidence threshold was selected [30]. BLAST analysis was performed on public $\mathrm{nr}$ database (Expect treshold 10 ; word size 28; 
Match/Mismatch Scores 1,-2) and culturable species that gave the closest sequence was used for specie identification.

\subsection{High-throughput experiment (experiment 1)}

\subsubsection{Optical measurement for microalgae population}

Bacterial effects on Dunaliella sp. SAG 19.3 growth were assessed by a screening experiment (experiment 1) using microplates cultures. Because direct measurement for carbon biomass was not available in microplate wells, we first tested in vivo $\mathrm{Chl} a$ fluorescence $(450 \mathrm{~nm}-685 \mathrm{~nm})$ and $\mathrm{OD}_{680}$ in order to assess microalgal biomass. The experiment aimed at defining whether either optical measurement gave reliable estimation for microalgae population in mixed culture, regardless of bacterial population. Accordingly, we mixed microalgal to bacterial suspensions in order to obtain different microalgal : bacterial concentration ratios meeting $2^{2 *}$ central composite design requirement and we further measured in vivo $\mathrm{Chl} a$ fluorescence and $\mathrm{OD}_{680}$. Five levels were used for the respective factors (i.e. microalgal and bacterial concentrations) by adding so-called star-points to the simple (square) 2-level factorial design points in order to assess quadratic component (figure 1). Three center point replicates were added to evaluate experimental variance. The distance between center points and star-points was calculated using the axial distance $\alpha=1.414$. Finally, 11 experiments were needed to incorporate this $2^{2 *}$ central composite design. . The general quadratic model fitted to the data is given in equation 1.

$R=\beta_{0}+\beta_{1} \mathrm{X}_{1}+\beta_{2} \mathrm{X}_{2}+\beta_{12} \mathrm{X}_{1} \mathrm{X}_{2}+\beta_{11} \mathrm{X}_{1}^{2}+\beta_{22} \mathrm{X}_{2}^{2}+\varepsilon$

equation 1

where $\beta_{\mathrm{i}}, \beta_{\mathrm{ij}}$, and $\beta_{\mathrm{ii}}$ are model coefficients, $X_{i}$ the main effect for the factor $i, X_{i j}$ the interaction between the factors $i$ and $j, X_{i}^{2}$ the quadratic effect of the factor $I, \varepsilon$ the residual error and $R$ the response (either in vivo $\mathrm{Chl} a$ fluorescence or $\mathrm{OD}_{680}$ ). Here, $X_{1}$ was chosen for microalgal concentration and $X_{2}$ for bacterial concentration.

An axenic culture of Dunaliella sp. was grown on enriched ASW. Bacteria (strain SY183) were grown on Marine Broth for $48 \mathrm{~h}$ at $20^{\circ} \mathrm{C}$, then centrifuged $\left(10000 \mathrm{~g}, 5 \mathrm{~min}, 20^{\circ} \mathrm{C}\right.$ ) to remove growth medium and resuspended in ASW. By mixing the axenic microalgal culture to the bacterial suspension, we were able to achieve different microalgae and bacterial concentration in 96-wells microplate, as shown in Figure 1. In vivo $\mathrm{Chl}$ a fluorescence (wavelength: excitation $=450 \mathrm{~nm}$, emission $=685 \mathrm{~nm}$ ) and $\mathrm{OD}_{680}$ were measured in mixed cultures with a TECAN (Mannedorf Switzerland) spectrofluorimeter.

\subsubsection{Experimental culture}

A specific high-throughput experimental set-up was devised to allow the use of three microplates to perform mixed cultures with replicates under homogenous conditions of irradiance and temperature. The device consists of an illuminating plate with 10 fluorescent tubes (OSRAM L13W/954). A PMMA diffusion plate is placed on the illuminating plate. The three clear-bottom microplates are then placed above. We tested a diversity of microplate and, ultimately, special 96 well black microplates (Costar ${ }^{\circledR} 3615$, Corning ${ }^{\circledR}$, USA) were chosen with clear bottoms made of $60 \%$ thinner polystyrene than standard, resulting in lower background fluorescence readings. To prevent contamination, wells were sealed with adhesive film (MicroAmp ${ }^{\circledR}$ Optical Adhesive Film, Applied Biosystems ${ }^{\circledR}$, USA) selected for its additional protection against evaporation, which can reach as much as $85 \%$ in 11 days when using some other tissue culture films. Irradiance and temperature were measured using a LiCor LI193 quantum scalar meter and a LM 35DZ sensor, respectively. The small size of the two sensors allowed measuring parameters inside the wells filled with ASW. This set-up 
provided a mean irradiance of $50 \mu \mathrm{mol}$ photons $\mathrm{m}^{-2} \mathrm{~s}^{-1}$ and irradiance field homogeneity with a $5.3 \%$ coefficient of variation $(n=117)$. Temperature was set at $19.4{ }^{\circ} \mathrm{C}$, while temperature variation between wells, estimated by the coefficient of variation, was $2.3 \%(n=38)$. Cultures were performed statically. Prior to readings with Tecan, cultures were homogenized by automatic shaking.

To start the experiment, bacterial strains were precultured in Marine Broth for 48 hours at 20 ${ }^{\circ} \mathrm{C}$. Bacterial cells were then harvested by centrifugation at $3000 \mathrm{~g}$ for $5 \mathrm{~min}$ at $20{ }^{\circ} \mathrm{C}$. Associations with the axenic culture of Dunaliella sp. were made-up at the initial ratio of around 10 bacterial cells per microalgal cell, with a concentration of Dunaliella $s p$. cells of 2 $\mathrm{x} 10^{5}$ cell. $\mathrm{mL}^{-1}$ in both the axenic and mixed cultures. The culture medium consisted of ASW enriched with Walne"s medium without vitamins and modified for nitrogen. To test bacteria for their ability to remineralize nitrogen, cultures were grown under nitrogen limitation, with the addition of ammonium to obtain a nitrogen concentration of $547.8 \mu \mathrm{M}$, resulting in a molar nitrogen:phosphorus ratio of 3.3:1. Since the adhesive film was not permeable to gas, carbon limitation was prevented by adding $10 \mathrm{mM}$ of $\mathrm{NaHCO}_{3}$.

Growth of microalgae was monitored by in vivo $\mathrm{Chl}$ a fluorescence (wavelength: excitation = $450 \mathrm{~nm}$, emission $=685 \mathrm{~nm}$, TECAN Mannedorf Switzerland). Three measurements per day were performed during the first 17 days and one or two measurements per day until day 20 . Testing for bacterial contamination was done on Marine Agar plates at the end of the experiment.

\subsection{Flask cultures (experiment 2)}

\subsubsection{Bacterial quotas}

Preliminary microscopic observations revealed that bacterial size and shape were different for the three bacterial strains SY003, SY007 and SY244. We recorded that more than $95 \%$ of bacteria cells in mixed cultures were retained on precombusted GF/C filters. In order to evaluate the contribution of bacteria to total particulate $C$ and $N$ recovered on GF/C filters, we assessed carbon $\left(Q_{C}\right)$ and nitrogen $\left(Q_{N}\right)$ quotas for the three bacterial strains tested: bacterial cultures were incubated in Marine Broth medium for $48 \mathrm{~h}$ at $20^{\circ} \mathrm{C}$ and $300 \mathrm{rpm}$. After centrifugation $\left(10000 \mathrm{~g}, 5 \mathrm{~min}, 20^{\circ} \mathrm{C}\right.$ ), cells were resuspended in fresh ASW and cell concentration was assessed by cytometer (BD Accuri Cytometer). Bacterial particulate $\mathrm{N}$ and C were estimated : a given volume of cell suspension was filtered in triplicate on precombusted $25 \mathrm{~mm}$ GF/C filters (Whatman, $1.2 \mu \mathrm{m}$ ). Filters were then dried for 24 hours at $70^{\circ} \mathrm{C}$ and further analysed using a CN Elemental Analyzer (Flash 2000,Thermoscientific). Since all bacterial strains in the xenic culture could not be cultivable in Marine Broth medium, we estimated mean quotas from cell volume (as assessed from microscopic observations). Indeed, these bacteria demonstrated size and shape very similar to that observed for SY003. We therefore considered same quotas for $\mathrm{SY003}$ and bacteria in the xenic culture.

\subsection{2. experimental culture}

Following the screening in experiment 1 , three microalgae-bacteria associations and the initial xenic and axenic cultures were selected for further comparative investigation (experiment 2). The axenic culture was considered as the control. Algae-bacteria associations were maintained for several months at $20{ }^{\circ} \mathrm{C}$ before experiment 2 , with successive batch cultures on enriched ASW under a continuous irradiance of $100 \mu \mathrm{mol}$ photons $\mathrm{m}^{-1} \mathrm{~s}^{-1}$. Cells were harvested to eliminate residual nutrients, and then transferred into flasks. Triplicate cultures were conducted in sterile $1 \mathrm{~L}$-glass flasks with a supply of $0.22 \mu \mathrm{m}$ 
filtered air (Midisart, Sartorius). We specifically paid attention to reproduce culture conditions as close as possible to that in experiment 1 in order to readily compare results. The medium used was similar to that for experiment 1 ( $\mathrm{N}$ source, $\mathrm{N}: \mathrm{P}$ ratio, $\mathrm{NaHCO}_{3}$ enrichment, no vitamins added). Temperature was set at $20{ }^{\circ} \mathrm{C}$ and irradiance was set to a higher level $\left(250 \mu \mathrm{mol}\right.$ photons $\left.\mathrm{m}^{-2} \mathrm{~s}^{-1}\right)$ than in experiment 1 to compensate for the higher optical path length in flasks.

Cultures were sampled daily for microalgae cell density and cell size, as measured with a HIAC cell counter (Hach Ultra, USA). Cell biovolume was computed from mean cell diameter under the assumption of a sperical shape for Dunaliella sp. Total particulate $\mathrm{C}$ and $\mathrm{N}$ were also estimated as previously described for bacteria (see 2.4.1). Microalgal $\mathrm{N}$ and $\mathrm{C}$ recovered on GF/C filters were then calculated as the difference between total particulate and bacterial $\mathrm{N}$ and $\mathrm{C}$. Finally, $\mathrm{N}$ incorporation was computed as the percentage of initial $\mathrm{N}$ $\mathrm{NH}_{4}$ enrichment $(547.8 \mu \mathrm{M})$ incorporated in microalgae cells at stationary phase.

In order to validate $\mathrm{N}$ starvation at the end of the experiments, cultures were re-enriched with $547.8 \mu \mathrm{mol}$ of ammonium, and the biomass increase was verified over the following days.

The density of bacterial cells was measured by cytometric analysis at the beginning of the experiment, during the growth phase and at the stationary phase. The bacterial population was identified by cytometer (BD Accuri Cytometer) after coloration with SYBRgreen. Bacteria to microalgae ratio (B:A, cell:cell) was calculated from cytometric data for bacteria and from HIAC data for algae.

Absence of bacterial contamination at the end of the experiment was assessed by RAPD analysis on randomly selected strains after isolation on Marine Agar plates. Extraction and PCR reactions were performed using the same mixture as described above. Analyses were applied twice with Amersham@ RAPD Analysis Primer 1 (5'- GGTGCGGGAA-3') and 4 (5'AAGAGCCCGT-3'). The cycling program was as follows: 5 min at $94{ }^{\circ} \mathrm{C}, 45$ cycles including $1 \mathrm{~min}$ at $94{ }^{\circ} \mathrm{C}, 1 \mathrm{~min}$ at $36{ }^{\circ} \mathrm{C}$ and $2 \mathrm{~min}$ at $72{ }^{\circ} \mathrm{C}$. PCR products were separated on $2 \%$ TAE agarose gels and the profiles obtained were compared to the original bacterial reference strain from the collection. RAPD analyses were produced with the Bionumerics software (V6.01) by using a band-based similarity index.

\subsection{Estimation of growth and statistics}

Maximal growth rate, $\mu_{\max }\left(\mathrm{d}^{-1}\right)$ of Dunaliella $s p$. was computed according to equation 1 from the linear part of the In-transformed growth curve:

$$
\mu_{\max }=\frac{\Delta \ln X}{\Delta t}
$$

Equation 2

where $X$ is either Chl a fluorescence (experiment 1) or particulate carbon (experiment 2) during the exponential growth phase and $t$ is time in days. Since bacterial carbon contributed to a low level to total particulate carbon recovered on GF/C filters, microalgae $\mu_{\max }$ could be computed from total particulate carbon data in experiment 2.

Maximal biomass increase $\Delta X_{\max }$ of Dunaliella $s p$. was computed at stationary phase according to equation 2:

$$
\Delta X_{\max }=X_{f}-X_{i}
$$

Equation 3

where $X_{f}$ and $X_{i}$ are either $\mathrm{Chl}$ a fluorescence (experiment 1) or particulate carbon (experiment 2), respectively at the stationary phase and at the beginning of the culture. 
Since $\Delta X_{\max }$ was computed from fluorescence readings in experiment 1 and from particulate carbon in experiment 2, comparison for $\Delta X_{\max }$ between the two experiments was performed after normalization according to equation 3 :

$\Delta X_{\max }^{\text {norm }}=\frac{\Delta X_{\max }-\Delta \bar{X}_{\max }}{\sigma}$

Equation 4

Where $\Delta \bar{X}_{\max }$ is mean maximal biomass increase and $\sigma$ is standard deviation in experiment.

Statistical analyses were performed with Statgraphics ${ }^{\circledR}$ software for the factorial design approach and R software (GNU project) elsewhere. Since experiments 1 and 2 involved only triplicate cultures, results are expressed hereafter as median and interquartile range (IQR) rather than mean and standard error. In experiment 2, effects of bacteria on microalgal parameters were tested using the Kruskal Wallis test $(\alpha=5 \%)$. The comparison of growth parameters computed from the two experiments was carried out using Spearman"s rank correlation coefficient $(\alpha=5 \%)$.

\section{Results}

\subsection{Purification of Dunaliella sp. SAG 19.3 culture}

An axenic culture of Dunaliella sp. strain SAG 19.3 was obtained successively to the repeated antibiotic treatment. No cultivable bacteria were observed on the Marine Agar plates inoculated with samples of this algal culture. In addition, before the use of this Dunaliella $s p$. culture for experiments, absence of uncultivable strains was systematically verified by epifluorescence microscopy after SYBRgreen staining.

\subsection{Bacterial collection}

Forty-eight strains of bacteria were isolated from 19 microalgae species, of which $71 \%$ were acquired from diatoms. In the collection, analysis for partial 16S rRNA revealed that 37 strains were gram-negative, of which 8 belong to Cytophaga-Flavobacterium-Bacteroides (CFB) including 2 sphingobacteria and 6 flavobacteria, 17 to Alphaproteobacteria and 12 to Gammaproteobacteria. Eleven strains were gram-positive including 10 Actinobacteria and one Bacilli (Table 1).

\subsection{High-throughput selection (experiment 1)}

\subsection{1. optical measurement for microalgae population}

The factorial approach used to compare $\mathrm{OD}_{680}$ to fluorescence as proxies for microalgae population resulted in both models explaining more than $99 \%$ of the variability observed on data. Both $\mathrm{OD}_{680}$ and fluorescence were significantly $(\alpha=0.01)$ and positively related to microalgal concentration (Table 2). For $\alpha=0.01$, neither quadratic effects nor interaction between microalgae and bacterial concentration were found significant for both measurements. However, as shown in Table 2, $\mathrm{OD}_{680}$ readings increased with bacterial concentration, while fluorescence was not significantly affected.

\subsubsection{Effect of bacteria on maximal growth rate}

High-throughput experiment was carried out for 20 days, until all cultures have reached stationary phase. Bacterial isolation on Marine Agar plates confirmed that no contamination occurred at the beginning or the end of the experiment in mixed or axenic cultures. Maximal 
growth rate ( $\mu$ max) of Dunaliella sp. ranged from $0.23 \mathrm{~d}-1$ to $0.36 \mathrm{~d}-1$ depending on bacterial association, with $0.36 \mathrm{~d}-1$ (0.01) for the axenic control (Figure 2). Addition of bacteria to Dunaliella sp. cultures mostly resulted in slight negative effects on $\mu$ max, although some other bacterial strains did not alter microalgae $\mu$ max. No bacterial enhancement of growth rate was observed in this experiment. The growth-inhibiting bacteria were broadly distributed across taxomonic groups (Figure 2 ; Table 1$)$. The strongest negative effect $(-36 \%)$ was obtained for the xenic Dunaliella sp. culture. Interestingly, 3 bacterial strains isolated from this xenic culture (Rhodococcus fascians SY001, SY002 and Dietzia sp. SY250) resulted in negative effects $(-18 \%,-11 \%$ and $-22 \%$, respectively) when tested individually. Muricauda sp. strain SY244 isolated from Thalassiosira sp., resulted in a $22 \%$ decrease in Dunaliella sp. growth rate. Another Muricauda strain (SY186) also had an inhibitory effect on $\mu$ max (-18 $\%)$. The addition of certain strains resulted in lesser reductions in $\mu$ max, such as with Halomonas sp. SY003 (-12 \%) and Alteromonas sp. SY007 (-7 \%).

Fourteen strains exhibited $\mu_{\max }$ close to the control, such as the strains affiliated to Arthrobacter sp. SY004 and to Bacillus foraminis SY097, for example (Figure 2).

\subsubsection{Effect of bacteria on maximal biomass increase}

Maximal biomass increase $\left(\Delta X_{\max }\right)$ measured at stationary phase was more strongly altered by bacterial addition than $\mu_{\max }$ (Figure 2). Effects ranged from $-57 \%$ to $+26 \%$ and were mainly negative. The strongest negative effect $(-57 \%)$ was observed for the xenic Dunaliella sp. culture. Strains SY001 and SY002 isolated from the xenic culture and affiliated with Rhodococcus fascians also decreased $\Delta X_{\max }$ with strong effects (-42\% and $\left.-44 \%\right)$.

Twenty-one bacterial strains resulted in $\Delta X_{\max }$ close to that of the axenic control (Figure 3 ). However, $\Delta X_{\max }$ was enhanced by $22 \%$ and $26 \%$ when Dunaliella sp. was associated with bacteria SY007 and SY244 affiliated to Alteromonas sp. and Muricauda sp., respectively. These bacteria were isolated from diatom cultures: Thalassiosira $s p$. for the Alteromonas $s p$. SY007, and Phaeodactylum tricornutum for the Muricauda sp. SY244.

\subsection{Flask cultures (experiment 2)}

Following experiment 1 , three bacterial strains were selected for the different alteration pattern they brought about in Dunaliella sp.. Alteromonas sp. SY007 and Muricauda sp. SY244 were selected for their enhancing effect on Dunaliella $s p$. maximal biomass increase $\left(\Delta X_{\max }\right)$ at the stationary phase (Figure 3 ). Halomonas sp. SY003 was also selected as an example of a $\Delta X_{\max }$-inhibiting bacteria. These three mixed cultures were compared to the control axenic strain and to the original xenic strain SAG19.3.

\subsubsection{Bacterial populations}

First of all, no bacterial contamination was observed on Marine Agar plates along the course of experiment. Cytometry analysis confirmed these results since we observed no events corresponding to bacteria in the axenic cultures, and only one uniform bacterial population on cytograms for mixed cultures. RAPD profile analyses of bacteria isolated at the end of the experiment 2 showed $100 \%$ similarity with the corresponding reference bacterial strain (Figure 4), regardless of the primer used (RAPD1 or RAPD4). Similarity was lower (90\%) only for Halomonas SY003 C1 strain isolated from flask F1, when RAPD1 was used, but was $100 \%$ with RAPD4. Considering the high sensitivity of the technique, we concluded that bacterial strains at the end of experiment 2 were similar to that inoculated. 
The bacterial population, estimated at $t_{0}, t_{5}$ and $t_{10}$ by cytometry analysis, developed in all mixed cultures (Figure 5B). The highest bacterial cell density was recorded in the mixed culture SY003. At the stationary phase, the bacteria to microalgae ratio (B:A, cell:cell) in this culture was also particularly high: 777 bacteria cells per algae. Differences were observed at the stationary phase in B:A for strains SY007 and SY244, being 39 for SY007 and only 8 for SY244. Finally, the lowest bacteria increase and B:A level, 2 bacteria per algae, was recorded in the xenic cultures of Dunaliella $s p$. Epifluorescence microscopy observations after sybrgreen dyeing revealed that, for all mixed cultures, bacteria cells were free in the medium and not attached to the surface of living algal cells.

Nitrogen $\left(\mathrm{Q}_{\mathrm{N}}\right)$ and carbon $\left(\mathrm{Q}_{\mathrm{C}}\right)$ cell quotas measured for the three bacterial strains are presented in Table 3. From quotas and bacterial cell population data, we could compute bacterial contribution to total particulate $\mathrm{N}$ and $\mathrm{C}$ recovered on $\mathrm{GF} / \mathrm{C}$ filters. It followed that bacterial carbon represented less than $4 \%$ of total particulate carbon in all mixed cultures, except for SY003 where it was $10 \%$ of total particulate carbon. Bacteria contributed to higher level of total particulate $\mathrm{N}$, bacterial $\mathrm{N}$ being as high as $34 \%$ for SY003 and $15 \%$ for SY007 (Table 3).

\subsubsection{Microalgae growth}

As already mentioned above, contribution of bacteria to total particulate carbon was low in mixed cultures. Therefore we assumed that total particulate carbon recovered on GF/C filters was a suitable proxy for microalgal carbon and in the following, we further compare microalgae growth computed from total particulate carbon data.

Growth of Dunaliella $s p$. in flasks was very sensitive to the bacterial strain added in the culture, as illustrated in Figure $5 \mathrm{~A}$ by the different growth curves recorded during experiment 2. Microalgae $\mu_{\max }$ computed on a per-carbon basis in experiment 2 (Table 4) were very similar to those computed from in vivo $\mathrm{Chl}$ a fluorescence in experiment 1 . Indeed, a positive correlation $\left(\rho=0.91 ; \mathrm{P}\right.$ value $=0.042 ;$ slope $=1.0$ ) was found for $\mu_{\max }$ recorded in the two experiments. As previously observed in the high-throughput experiment, the addition of bacteria to the cultures did not result in an enhancing effect for $\mu_{\max }$ when compared with the axenic cultures of Dunaliella sp. (Table 4). The lowest $\mu_{\max }$ were observed in xenic cultures and when Halomonas sp. SY003 and Muricauda sp. SY244 were added to cultures. Interestingly, no significant difference with the axenic control was obtained when Dunaliella $s p$. was associated to Alteromonas sp. SY007.

At the stationary phase in experiment 2, bacterial addition resulted in altered $\Delta X_{\max }$ for Dunaliella $s p$. Again, results recorded in experiment 2 were similar to those of experiment 1 and a positive correlation ( $\rho=0.95 ; P$ value $=0.042$; slope $=1.0$ ) was obtained for normalized $\Delta X_{\max }$ between the two experiments. The lowest $\Delta X_{\max }$ were observed in experiment 2 for xenic cultures $(-25 \%)$ and when Halomonas sp. SY003 (-33\%) was associated with Dunaliella sp. (Table 4). In addition, similar enhancing effects were observed in mixed cultures SY007 (+31\%) and SY244 (+35\%). These two bacteria significantly increased carbon accumulation in microalgae cultures compared with the axenic control and, more strongly, when compared to the original SAG 19.3 xenic strain.

Microalgae cell size was also significantly affected by bacterial addition. We were able to compute biovolume of microalgae cells (Table 4) on the basis of Hiac data, assuming a spherical shape for Dunaliella $s p$. We found a positive correlation $(\rho=0.98 ; P$ value $=0.003)$ between biovolume and carbon quota in microalgae. We recorded high microalgal biovolume for SY244 and the axenic cultures, while cells in the xenic cultures were significantly smaller. 


\subsubsection{Nitrogen incorporation}

In order to estimate nitrogen incorporation in microalgae, we corrected total particulate $\mathrm{N}$ for bacterial $\mathrm{N}$. Indeed, we found that bacterial $\mathrm{N}$ could contribute to high level to total particulate $\mathrm{N}$ recovered on GF/C filters (up to $34 \%$ at stationary phase for SY003). From data of bacterial $\mathrm{N}$ quota and bacterial population we could substract bacterial $\mathrm{N}$ to total particulate $\mathrm{N}$ and estimate $\mathrm{N}$ incorporation for microalgae. At the stationary phase, the resulting microalgal C:N (Table 4) was high (22.8 to 29.6) for the different cultures, compared to the C: $N$ ratio recorded at $\mu_{\max }(\mathrm{C}: \mathrm{N}=6$, data not shown).

It followed that bacterial addition significantly altered $\mathrm{N}$ incorporation for Dunaliella $s p$. (Table 4). The lowest $\mathrm{N}$ incorporation in microalgae was obtained in SY003 cultures (19\%) while axenic (26\%) and xenic (34\%) demonstrated intermediate $\mathrm{N}$ incorporation. In mixed cultures with Muricauda sp. SY244 and Alteromonas sp. SY007, N incorporation was significantly enhanced up to $56 \%$ of the initial $\mathrm{N}$ enrichment.

\section{Discussion}

\subsection{Microalgae culture-based bacterial collection}

Isolation of bacteria from a diversity of monospecific microalgal cultures provided a bacterial collection of 48 strains. Since these bacteria strains developped in microalgae cultures without organic carbon supplementation, we suspected that they were able to grow on the organic carbon released by microalgae. This suggested interactions between bacteria and Dunaliella sp.. A high bacterial diversity with low redundancy was recorded. Indeed, bacterial strains isolated from different microalgal cultures were mostly different, with the strains well distributed among four phylogenetic clusters: $\alpha$ - and $\gamma^{-}$Proteobacteria, CytophagaFlavobacterium-Bacteroides and gram-positive mainly affiliated to Actinobacteria. This study aimed at providing a bacterial collection for further interaction studies and did not encompass an ecological scope since only dominant and cultivable bacteria were recovered from microalgal cultures. However, it should be noted that we isolated and identified bacterial groups that were previously observed elsewhere, following isolation of bacteria from microalgae cultures in hatcheries [31] and in bacterioplankton communities [32-34]. No members of the $\beta$-Proteobacteria were recovered from this collection, although this cluster has been recorded in several ecological studies [35,36]. Again, this absence could result from the experimental set-up, as only dominant cultivable bacteria were considered here. In addition, the marine origin of this bacterial cluster has been debated in previous studies $[37,38]$.

\subsection{Methodological aspects}

\subsubsection{High-throughput selection of growth-promoting bacteria}

Most of the previous studies conducted on interactions between microalgae and bacteria have been carried out in Erlenmeyer or larger flasks [12,39]. However, these culture volumes are not suitable for the screening of a large number of species at once. Therefore, we developed a specific experimental device based on microplates. Similar tools have been previously used to assess growth for microalgae [40]. However, in this study, we had to face specific constraints, including the presence of bacteria that can affect optical measurements for microalgae concentration and bacterial cross-contamination between wells. With the use of the impermeable film together with $\mathrm{NaHCO} 3$ addition in culture medium we were able to prevent cross-contaminations between wells and carbon limitation in the absence of gas exchange. The novelty of this setup consists in the possibility to screen microalgal and 
bacterial mixed cultures and to evaluate associated yields thanks to the selection of adapted materials, controlled environmental parameters (temperature, light, contamination, evaporation) and the use of fluorescence to monitor microalgae growth without bacteria population disturbance.

Unlike $\mathrm{OD}_{680}$ measurement, fluorescence $(450 \mathrm{~nm}-685 \mathrm{~nm})$ was insensitive to bacteria concentration (Table 2) and could be seen as a reliable proxy for microalgae population assessment in microplate. Additionally, comparison between microplate and flask experiments revealed similar trends for both growth parameters, as illustrated by the Spearman"s rank correlation coefficients found here. These results confirmed that indirect measurements for microalgae growth using in-vivo fluorescence gave consistent results with direct measurements for microalgal particulate carbon.

The high correlation coefficient mentioned above for both growth parameters in the two experiments also suggested that the low culture volume $(300 \mu \mathrm{L})$ in microplate, combined with the use of impermeable adhesive film, is a reliable culture system for Dunaliella $s p$. By paying particular attention to light and temperature variability between plates and wells, we managed to reduce the coefficient of variation (CV) to $5.3 \%$ and $2.3 \%$, respectively. As a consequence, we recorded only low variability between culture replicates, particularly for growth rate. Finally, the high throughput technique confirmed to be a time-saving approach since set-up of experiment can be achieved within hours easily and fluorescence reading is fast enough to allow several readings per day. Together, these benefits may afford the use of a higher number of replicates to even increase system reliability. As such, the proposed highthroughput device proved to be an efficient tool to qualitatively assay the effect of a high number of bacterial strains on microalgae growth.

\subsubsection{Assessment of compartimentation between microalgae and bacteria}

In experiment 2, the use of GF/C filters did not allow to separate microalgae from bacteria. Hence, in order to estimate $\mathrm{N}$ and $\mathrm{C}$ incorporation in microalgae, we first measured bacterial $\mathrm{N}$ and $\mathrm{C}$ quotas with pure bacterial cultures, as already reported elsewhere [41]. We did not have evidence for growth capacity on Marine Broth of all bacteria strains found in the xenic culture. Hence, we could no reliably measure quotas for these bacteria. However, bacteria strains in the xenic culture and SY003 exhibited similar shape and size and we considered C and $\mathrm{N}$ quotas similar to that for $\mathrm{SYO03}$ (Table 3). We point out that since bacterial population remained low in the xenic culture (see Figure 5B), bacteria contributed to a very low level to $\mathrm{N}$ and $\mathrm{C}$ recovered on GF/C filters (Table 4), irrespective of the assumption for quotas. We then substracted the bacterial compartment from total particular matter recovered on filters to compute microalgae $\mathrm{N}$ and $\mathrm{C}$. This approach resulted in high $\mathrm{C}: \mathrm{N}$ for microalgae at stationary phase in mixed and axenic cultures, a result in accordance with the Droop quota theory [42] that $\mathrm{N}$-limited microalgae cells stop growth at a given maximum $\mathrm{C}: \mathrm{N}$. By the way, this result and the good correlation found between microalgae biovolume and $\mathrm{Q}_{\mathrm{C}}$, also supported our approach for microalgae $\mathrm{N}$ and $\mathrm{C}$ computation. Finally, the high $\mathrm{C}: \mathrm{N}$ recorded here were in accordance with $\mathrm{N}$ limitation for microalgae at stationary phase as assessed by $\mathrm{N}$ re-supplementation at the end of the experiment.

\subsection{Effect of bacteria on growth of Dunaliella sp.}

The high-throughput experiment (experiment 1) was designed so as to rapidly focus on microalgae-bacteria associations altering growth performance for Dunaliella sp., that could be further characterized in the successive flask experiment. The experiment resulted in a number of inhibition and/or promotion effects (Figure 2 and 3) on Dunaliella sp. $\mu_{\max }$ and $\Delta X_{\text {max }}$. Most of the 48 bacterial strains tested in experiment 1 negatively affected microalgal 
$\Delta X_{\max }$ and $\mu_{\max }$. However, effect on microalgal growth rate was only slight compared to the wide range we recorded for $\Delta X_{\max }$. Since cultures were grown without vitamin supplementation, we expected that some associations could result in increased microalgae $\mu_{\max }$. Yet, we did not record any microalgal $\mu_{\max }$ improvement, demonstrating that synthesis of growth-promoting compounds [11-13] by bacteria did not occure or was not efficient. Finally, we were unable to find connection between bacterial taxonomic position and effect on Dunaliella sp. growth. However, as pointed out by Mayali and Azam [43] for algicidal bacteria, the question of metabolic properties common to broad bacterial taxa remains largely unanswered.

In experiment 2, we focused on three bacterial strains that produced various effects on microalgae $\mu_{\max }$, while altering $\Delta X_{\max }$ : Alteromonas $s p$. SY007, Muricauda sp. SY244 and Halomonas sp. SY003; Effects that were recorded with the bacterial strains in experiment 1 were confirmed in the flask experiment for both $\mu_{\max }$ and $\Delta X_{\max }$. Assumptions for the underlying mechanisms are discussed in the following.

It is well known that bacteria can modify microalgal growth by affecting either growth rate or biomass accumulation. Maximal growth rate of microalgae is likely to be affected by bacterial population, possibly with an enhancing effect, as previously observed in the literature [39,44], but not in this study. Several authors have demonstrated that the negative effects of bacteria on $\mu_{\max }$ are the result of the excretion of toxic bacterial compounds; this issue has been frequently addressed in studies dealing with the impact of algicidal bacteria on algal blooms $[43,45,46]$. Several bacterial genera (Cytophaga, Dietzia, Janibacter, Micrococcus, Pseudoalteromonas) referenced in our collection that led to decreased $\mu_{\max }$ for Dunaliella $s p$. in culture, have been precisely described as algicidal bacteria in the literature $[47,48]$.

Bacterial effects on biomass accumulation at the stationary phase have also been previously reported in the literature [49,50]. Mouget et al. observed a strong increase $(+50 \%)$ in maximal cell density for Scenedesmus bicellularis associated with a Brevundimonas diminuta strain [51]. Tai et al. suggested the occurrence of Vibrio species in ammonium production, supporting Synechococcus sp. growth [14]. Besides, it is well known that nitrogen excretion occurs during microalgae batch culture [52]. Since nitrogen-limited conditions were used in this study, it was assumed that nitrogen remineralization of organic nitrogen released by microalgae occurred in cultures where Alteromonas sp. SY007 and Muricauda sp. SY244 were added. Bacterial remineralization of extracellular organic matter, originating from algal cells death and/or algal organic excretion, could provide ammonium and delay nitrogen starvation for Dunaliella sp.. Indeed mineralization of microalgal organic $\mathrm{N}$ is well documented in the presence of bacteria [53-55]. Brussaard and Riegman [56] demonstrated that bacteria reduced death rates of $\mathrm{N}$-starved Ditylum brightwellii and the authors assumed that mineralized ammonium was probably partly utilized by microalgal cells. Furthermore, they pointed out that, under $\mathrm{N}$-limited conditions, both bacteria and microalgae could benefit from each other. Our hypothesis is strenghthened by the higher $\mathrm{N}$ incorporation in Dunaliella $s p$. cells when mixed with one of the two bacterial strains, as compared with the axenic control. With the same nitrogen supply in the medium at the beginning of the experiment for all cultures, a higher amount of mineral nitrogen is available for microalgae growth thanks to algal organic matter recycling by bacteria. We consequently obtained a higher algal biomass reached at the stationary phase, compared to the axenic control. From these results, bacteria SY007 and SY244 could be considered as helpers for $\mathrm{N}$ assimilation for Dunaliella sp. cells. However, there is a need for further experiments with measurements for dissolved inorganic and organic nitrogen and microalgal particulate nitrogen to test this assumption.

Bacterial strains can also decrease $\Delta X_{\max }$ of microalgae by competing for a limiting nutrient. Such an effect has been previously reported by Meseck et al. for nitrogen, and by Rhee et al. and Danger et al. for phosphorus [7,50,57]. Alternatively, release of toxic compounds by bacteria could also be involved in the inhibitory effect observed at the stationary phase 
$[49,58]$. We assumed that the low microalgal biomass accumulation recorded for SY003 cultures could result from competition between bacteria and microalgae for the limited nitrogen. Indeed, the latter hypothesis was supported, since high bacterial concentration occurred at stationary phase in SY003 cultures, with $24 \%$ of the supplemented N incorporated in bacterial cells, while $\mathrm{N}$ incorporation in microalgae $(19 \%)$ was lower than that recorded in axenic cultures (26\%).

Xenic cultures exhibited significantly lower $\mu_{\max }$ and $\Delta X_{\max }$ than axenic cultures in both experiments. Rhodococcus fascians (SY001 and SY002) and Dietzia sp. (SY250) isolated from the xenic culture of Dunaliella sp. SAG 19.3 and assayed individually also depressed microalgal growth performance. Interestingly, we identified Rhodococcus fascians strains in the xenic culture that had been previously described by Sim-Mateo et al. as a phytopathogenic bacteria involved in gall formation [59]. In addition, Dietzia bacteria are also known as algicidal bacteria [48]. This result highlights the usefulness of testing bacterial populations in microalgae cultures. Indeed, at the industrial scale where axenic conditions can hardly be attainable, especially in open culture systems, sustainable association of microalgae with selected bacteria could improve performance for microalgae culture.

Interactions between bacteria and microalgae are complex mechanisms and may result in different pattern depending on conditions and protagonists involved in. Indeed, our results highlighted that interactions between microlgae and bacteria are highly species specific. This was already pointed out by Brussaard and Riegman who suggested that "species-specific differences in the response of nutrient deficient phytoplankton to the presence of bacteria do exist" [56]. Culture conditions can also substantially affect the outcome of interactions in mixed cultures, since they may affect composition and rates of algal exudation. Hence, it is suspected that the outcome of mixed cultures under $\mathrm{N}$-limited conditions would differ depending on batch or continuous culture mode as well as microalgal growth rate. Additionally, environmental factors such as temperature can affect microalgal organic $\mathrm{N}$ remineralization rates [53,54]. Finally, we also suspect that initial microalgae : bacteria ratio is another central issue in mixed culture and may turn symbiosis into competition for the mineral $\mathrm{N}$ resource : high ratios would favor competition for the mineral $\mathrm{N}$ resource, while low ratios could result in higher $\mathrm{N}$ availability for microalgae, as reported here for SY244 and SY007.

\section{Conclusion}

A specific microplate-based experimental design was developed to screen bacteriaDunaliella $s p$. associations and to select microalgae growth-promoting bacteria. From the comparison of results in a flask experiment, it was concluded that the experimental device was a powerful tool for high- throughput examination of the bacterial effect on microalgal growth. Two bacteria strains affiliated to Alteromonas $s p$. and Muricauda sp. particularly enhanced biomass accumulation for Dunaliella $s p$. A strong increase was also recorded in $\mathrm{N}$ incorporation, which suggested that $\mathrm{N}$ availability for microalgae was affected by these bacteria. Further research is needed for a precise assessment of the underlying mechanisms of these interactions. Nevertheless, the results of the present study suggest that culture performance can be substantially modified by bacteria, resulting in increased culture productivity, which is of particular interest for industrial production. 


\section{Acknowledgements}

This publication presents research results supported by the ANR BIOE 2008 Symbiose Project (http://anr-symbiose.org/?q=en/node/83). We would like to thank the Bureau de Traduction de I"Université de I'UBO, Brest, France, for improving the English.

\section{References}

[1] P. Spolaore, C. Joannis-Cassan, E. Duran, A. Isambert, Commercial applications of microalgae, Journal of Bioscience and Bioengineering, 101 (2006) 87-96.

[2] E. Molina Grima, E.-H. Belarbi, F.. Acién Fernández, A. Robles Medina, Y. Chisti, Recovery of microalgal biomass and metabolites: process options and economics, Biotechnology Advances, 20 (2003) 491-515.

[3] J. Park, H.-F. Jin, B.-R. Lim, K.-Y. Park, K. Lee, Ammonia removal from anaerobic digestion effluent of livestock waste using green alga Scenedesmus sp, Bioresource Technology, 101 (2010) 8649-8657.

[4] S.R. Subashchandrabose, B. Ramakrishnan, M. Megharaj, K. Venkateswarlu, R. Naidu, Consortia of cyanobacteria/microalgae and bacteria: Biotechnological potential, Biotechnology Advances, 29 (2011) 896-907.

[5] E. Fouilland, Biodiversity as a tool for waste phycoremediation and biomass production, Reviews in Environmental Science and Bio/Technology, 11 (2012) 1-4.

[6] I. Joint, P. Henriksen, G.A. Fonnes, D. Bourne, T.F. Thingstad, B. Riemann, Competition for inorganic nutrients between phytoplankton and bacterioplankton in nutrient manipulated mesocosms, Aquat Microb Ecol, 29 (2002) 145-159.

[7] G.-Y. Rhee, Competition between an alga and an aquatic bacterium for phosphate, Limnology and Oceanography, 17 (1972) 505-514.

[8] X. Mayali, G.J. Doucette, Microbial community interactions and population dynamics of an algicidal bacterium active against Karenia brevis (Dinophyceae), Harmful Algae, 1 (2002) 277-293.

[9] L. Verschuere, G. Rombaut, P. Sorgeloos, W. Verstraete, Probiotic Bacteria as Biological Control Agents in Aquaculture, Microbiol. Mol. Biol. Rev., 64 (2000) 655-671.

[10] R.E. Avendaño, C.E. Riquelme, Establishment of mixed-culture probiotics and microalgae as food for bivalve larvae, Aquaculture Research, 30 (2001) 893-900.

[11] J.J. Cole, Interactions between bacteria and algae in aquatic ecosystem, Annual Reviews of Ecology and Systematics, 13 (1982) 291-314.

[12] Y. Park, K.-W. Je, K. Lee, S.-E. Jung, T.-J. Choi, Growth promotion of Chlorella ellipsoidea by co-inoculation with Brevundimonas $\mathrm{sp}$ isolated from the microalga, Hydrobiologia, 598 (2008) 219-228.

[13] M.T. Croft, A.D. Lawrence, E. Raux-Deery, M.J. Warren, A.G. Smith, Algae acquire vitamin B12 through a symbiotic relationship with bacteria, Nature, 438 (2005) 90-93.

[14] V. Tai, I.T. Paulsen, K. Phillippy, D.A. Johnson, B. Palenik, Whole-genome microarray analyses of Synechococcus-Vibrio interactions, Environmental Microbiology, 11 (2009) 2698-2709.

[15] J. Liu, A.J. Lewitus, P. Brown, S.B. Wilde, Growth-promoting effects of a bacterium on raphidophytes and other phytoplankton, Harmful Algae, 7 (2008) 1-10. 
[16] L.E. De-Bashan, Y. Bashan, M. Moreno, V.K. Lebsky, J.J. Bustillos, Increased pigment and lipid content, lipid variety, and cell and population size of the microalgae Chlorella spp when co-immobilized in alginate beads with the microalgae-growth-promoting bacterium Azospirillum brazilense, Canadian Journal of Microbiology, 48 (2002) 514521.

[17] G.J. Doucette, Interactions between bacteria and harmful algae: A review, Natural Toxins, 3 (1995) 65-74.

[18] H.P. Grossart, M. Simon, Interactions of planktonic algae and bacteria: effects on algal growth and organic matter dynamics, Aquat Microb Ecol, 47 (2007) 163-176.

[19] A. Gardes, M.H. Iversen, H.-P. Grossart, U. Passow, M.S. Ullrich, Diatom-associated bacteria are required for aggregation of Thalassiosira weissflogii, ISME J, 5 (2011) 436445.

[20] B. Sialve, N. Bernet, O. Bernard, Anaerobic digestion of microalgae as a necessary step to make microalgal biodiesel sustainable, Biotechnol. Adv., 27 (2009) 409-416.

[21] M. Giordano, Interactions between $C$ and $N$ metabolism in Dunaliella salina cells cultured at elevated $\mathrm{CO} 2$ and high N concentrations, Journal of Plant Physiology, 158 (2001) 577-581.

[22] C.S. Weldy, M.H. Huesemann, Lipid Production by Dunaliella salina in Batch Culture: Effects of Nitrogen Limitation and Light Intensity, Journal Name: Journal of Undergraduate Research, VII:115-122; Journal Volume: 7, (2007) Medium: X.

[23] J.H. Mussgnug, V. Klassen, A. Schlüter, O. Kruse, Microalgae as substrates for fermentative biogas production in a combined biorefinery concept, Journal of Biotechnology, 150 (2010) 51-56.

[24] A. Ben-Amotz, J.E.W. Polle, D.V.S. Rao, The Alga Dunaliella: Biodiversity, Physiology, Genomics and Biotechnology, Science Publishers,U.S., 2009.

[25] J. Lyman, R.H. Fleming, Composition of seawater, Journal of Marine Research, 3 (1940) 134-146.

[26] P.R. Walne, Experiments in the large-scale culture of the larvae of Ostrea edulis L, Fishery Investigations. Series II, 25 (1966).

[27] J.-Y. Cho, J.-S. Choi, I.-S. Kong, S.-I. Park, R.G. Kerr, Y.-K. Hong, A procedure for axenic isolation of the marine microalga Isochrysis galbana from heavily contaminated mass cultures, Journal of Applied Phycology, 14 (2002) 385-390.

[28] M. Garnier, Y. Labreuche, J.-L. Nicolas, Molecular and phenotypic characterization of Vibrio aestuarianus subsp francensis subsp nov, a pathogen of the oyster Crassostrea gigas, Systematic and Applied Microbiology, 31 (2008) 358-365.

[29] J. Brosius, M.L. Palmer, P.J. Kennedy, H.F. Noller, Complete nucleotide sequence of a 16S ribosomal RNA gene from Escherichia coli, PNAS, 75 (1978) 4801-4805.

[30] Q. Wang, G.M. Garrity, J.M. Tiedje, J.R. Cole, Naïve Bayesian Classifier for Rapid Assignment of rRNA Sequences into the New Bacterial Taxonomy, Appl. Environ. Microbiol., 73 (2007) 5261-5267.

[31] J.-L. Nicolas, S. Corre, J.-C. Cochard, Bacterial Population Association with Phytoplankton Cultured in a Bivalve Hatchery, Microb Ecol, 48 (2004) 400-413.

[32] B.C. Crump, E.V. Armbrust, J.A. Baross, Phylogenetic Analysis of Particle-Attached and Free-Living Bacterial Communities in the Columbia River, Its Estuary, and the Adjacent Coastal Ocean, Appl. Environ. Microbiol., 65 (1999) 3192-3204.

[33] D.H. Green, L.E. Llewellyn, A.P. Negri, S.I. Blackburn, C.J.S. Bolch, Phylogenetic and functional diversity of the cultivable bacterial community associated with the paralytic 
shellfish poisoning dinoflagellate Gymnodinium catenatum, FEMS Microbiology Ecology, 47 (2004) 345-357.

[34] M. Sapp, A. Wichels, K.H. Wiltshire, G. Gerdts, Bacterial community dynamics during the winter-spring transition in the North Sea, FEMS Microbiology Ecology, 59 (2007) 622-637.

[35] J. Pinhassi, U. Zweifel, A. Hagstrom, Dominant marine bacterioplankton species found among colony-forming bacteria, Appl. Environ. Microbiol., 63 (1997) 3359-3366.

[36] N. Bano, J.T. Hollibaugh, Diversity and Distribution of DNA Sequences with Affinity to Ammonia-Oxidizing Bacteria of the $\beta$ Subdivision of the Class Proteobacteria in the Arctic Ocean, Applied and Environmental Microbiology, 66 (2000) 1960 -1969.

[37] H. Schäfer, B. Abbas, H. Witte, G. Muyzer, Genetic diversity of "satellite" bacteria present in cultures of marine diatoms, FEMS Microbiology Ecology, 42 (2002) 25-35.

[38] D.L. Kirchman, The ecology of Cytophaga-Flavobacteria in aquatic environments, FEMS Microbiol. Ecol., 39 (2002) 91-100.

[39] K. Watanabe, N. Takihana, H. Aoyagi, S. Hanada, Y. Watanabe, N. Ohmura, H. Saiki, $\mathrm{H}$. Tanaka, Symbiotic association in Chlorella culture, FEMS Microbiology Ecology, 51 (2005) 187-196.

[40] B. Skjelbred, B. Edvardsen, T. Andersen, A high-throughput method for measuring growth and loss rates in microalgal cultures, J Appl Phycol, 24 (2012) 1589-1599.

[41] K. Kogure, I. Koike, Particle Counter Determination of Bacterial Biomass in Seawater, Appl. Environ. Microbiol., 53 (1987) 274-277.

[42] M.R. Droop, Vitamin B12 and marine ecology IV The kinetics of uptake, growth and inhibition in Monochrysis lutheri, J. Mar. Biol., 48 (1968) 689-733.

[43] X. Mayali, F. Azam, Algicidal Bacteria in the Sea and their Impact on Algal Blooms1, Journal of Eukaryotic Microbiology, 51 (2004) 139-144.

[44] Suminto, Hirayama, Application of a growth-promoting bacteria for stable mass culture of three marine microalgae, Hydrobiologia, 358 (1997) 223-230.

[45] P.S. Salomon, I. Imai, Pathogens of Harmful Microalgae, in: E. Granéli, J.T. Turner (Eds.), Ecology of Harmful Algae, Springer Berlin Heidelberg, 2006: pp. 271-282.

[46] A.M. Amaro, M.S. Fuentes, S.R. Ogalde, J.A. Venegas, B.A. Suarez-isla, Identification and Characterization of Potentially Algal-lytic Marine Bacteria Strongly Associated with the Toxic Dinoflagellate Alexandrium catenella, The Journal of Eukaryotic Microbiology, 52 (2005) 191-200.

[47] I. Imai, D. Fujimaru, T. Nishigaki, M. Kurosaki, H. Sugita, Algicidal bacteria isolated from the surface of seaweeds from the coast of Osaka Bay in the Seto Inland Sea, Japan, African Journal of Marine Science, 28 (2006) 319-323.

[48] M.-J. Kim, S.-Y. Jeong, S.-J. Lee, Isolation, identification, and algicidal activity of marine bacteria against Cochlodinium polykrikoides, Journal of Applied Phycology, 20 (2008) 1069-1078.

[49] K. Fukami, T. Nishijima, Y. Ishida, Stimulative and inhibitory effects of bacterias on the growth of microalgae, Hydrobiologia, 358 (1997) 185-191.

[50] M. Danger, J. Leflaive, C. Oumarou, L. Ten-Hage, G. Lacroix, Control of phytoplankton-bacteria interactions by stoichiometric constraints, Oikos, 116 (2007) 1079-1086. 
[51] J. Mouget, A. Dakhama, M.C. Lavoie, J. Noüe, Algal growth enhancement by bacteria: Is consumption of photosynthetic oxygen involved?, FEMS Microbiology Ecology, 18 (1995) 35-43.

[52] M. Pujo-Pay, P. Raimbault, Improvement of the wet-oxidation procedure for simultaneous determination of particulate organic nitrogen and phosphorus collected on filters, Marine Ecology-Progress Series, 105 (1994) 203-203.

[53] A. Kamatani, Regeneration of inorganic nutrients from diatom decomposition, Journal of the Oceanographical Society of Japan, 25 (1969) 63-74.

[54] J.H. Garber, Laboratory study of nitrogen and phosphorus remineralization during the decomposition of coastal plankton and seston, Estuarine, Coastal and Shelf Science, 18 (1984) 685-702.

[55] Y. Tezuka, Bacterial regeneration of ammonium and phosphate as affected by the carbon:nitrogen:phosphorus ratio of organic substrates, Microbial Ecology, 19 (1990) 227-238.

[56] C.P.D. Brussaard, R. Brookes, A.A.M. Noordeloos, R. Riegman, Recovery of nitrogenstarved cultures of the diatom Ditylum brightwellii (Bacillariophyceae) upon nitrogen resupply, Journal of Experimental Marine Biology and Ecology, 227 (1998) 237-250.

[57] S.L. Meseck, B.C. Smith, G.H. Wikfors, J.H. Alix, D. Kapareiko, Nutrient interactions between phytoplankton and bacterioplankton under different carbon dioxide regimes, J Appl Phycol, 19 (2007) 229-237.

[58] A. Mitsutani, I. Yamasaki, H. Kitaguchi, J. Kato, S. Ueno, Y. Ishida, Analysis of algicidal proteins of a diatom-lytic marine bacterium Pseudoalteromonas sp strain A25 by twodimensional electrophoresis, Phycologia, 40 (2001) 286-291.

[59] C. Simón-Mateo, S. Depuydt, C.L. De Oliveira Manes, F. Cnudde, M. Holsters, K. Goethals, D. Vereecke, The phytopathogen Rhodococcus fascians breaks apical dominance and activates axillary meristems by inducing plant genes involved in hormone metabolism, Molecular Plant Pathology, 7 (2006) 103-112. 
Tables

Table 1 : bacterial collection isolated from microalgae cultures.

\begin{tabular}{|c|c|c|c|c|c|}
\hline Strain & Origin & $\begin{array}{l}\text { Partial 16S } \\
\text { rRNA sequence } \\
\text { ID }\end{array}$ & Class & Family & Blast results \\
\hline SY022 & Sketetonema costatum & HE589500 & \multirow{2}{*}{ Sphingobacteria } & Cyclobacteriaceae & Cytophagasp. \\
\hline SY049 & Rhodella violacea & HE589505 & & Cyclobacteriaceae & Cytophaga sp. \\
\hline SY010 & Odontella aurita & HE589497 & \multirow{6}{*}{ Flavobacteria } & Flavobacteriaceae & Flexithrix sp. \\
\hline SY121 & Odontella aurita & HE589507 & & Flavobacteriaceae & Flexithrix sp. \\
\hline SY088 & Emiliania huxleyi & HE589506 & & Flavobacteriaceae & Maribacter sp. \\
\hline SY221 & Chaetoceros $s p$ & HE589511 & & Flavobacteriaceae & Maribacter sp. \\
\hline SY186 & Chaetoceros pumilum & HE589509 & & Flavobacteriaceae & Muricauda sp. \\
\hline SY244 & Thalassiosira sp & HE589517 & & Flavobacteriaceae & Muricauda sp. \\
\hline SY097 & Chaetoceros calcitrans & HE995401 & Bacilli & Bacillaceae 1 & Bacillus foraminis \\
\hline SY233 & Thalassiosira pseudomona & HE589528 & \multirow{10}{*}{ Actinobacteria } & Intrasporangiaceae & Janibacter limosus \\
\hline SY234 & Thalassiosira pseudomona & HE589529 & & Intrasporangiaceae & Janibacter sp. \\
\hline SY004 & Isochrysis galbana & HE589520 & & Micrococcineae & Arthrobacter sp \\
\hline SY240 & Phaeodactylum & HE589530 & & Micrococcineae & Micrococcus sp \\
\hline SY241 & Phaeodactylum & HE589531 & & Micrococcineae & Micrococcus sp \\
\hline SY208 & Chaetoceros gracilis & HE589525 & & Nocardiaceae & Actinobacter sp \\
\hline SY001 & Dunaliella $s p$ & HE589518 & & Nocardiaceae & Rhodococcus fascians \\
\hline SY002 & Dunaliella $s p$ & HE589519 & & Nocardiaceae & Rhodococcus fascians \\
\hline SY090 & Chaetoceros pumilum & HE589522 & & Dietziaceae & Dietza mari \\
\hline SY250 & Dunaliella $s p$ & HE589534 & & Dietziaceae & Dietza sp. \\
\hline SY086 & Rhodomonas salina & HE589541 & \multirow{17}{*}{ Alphaproteobacteria } & Rhodospirillaceae & Thalassospira sp \\
\hline SY093 & Rhodomonas salina & HE589542 & & Rhodospirillaceae & Thalassospira xianheensis \\
\hline SY180 & Skeletonema marinoi & HE589555 & & Rhodospirillaceae & Nisaea sp. \\
\hline SY127 & Nannochloris $s p$ & HE995403 & & Erythrobacteraceae & Citromicrobium sp \\
\hline SY183 & Chaetoceros pumilum & HE589556 & & Phyllobacteriaceae & Hoeflea $s p$ \\
\hline SY148 & Chaetoceros pumilum & HE589550 & & Phyllobacteriaceae & Hoeflea sp \\
\hline SY191 & Chaetoceros pumilum & HE589558 & & Phyllobacteriaceae & Hoeflea sp \\
\hline SY228 & Chaetoceros reptans & HE589562 & & Rhodobacteraceae & Stappia $s p$ \\
\hline SY052 & Chaetoceros pumilum & HE589538 & & Rhodobacteraceae & Haematobacter massiliensis \\
\hline SY133 & Skeletonema marinoi & HE589545 & & Rhodobacteraceae & Roseobacter sp. \\
\hline SY029 & Odontella aurita & HE589537 & & Rhodobacteraceae & Thalassococcus sp. \\
\hline SY245 & Chaetoceros gracilis & HE589563 & & Rhodobacteraceae & Sulfobacter sp. \\
\hline SY143 & Emiliania huxleyi & HE589548 & & Rhodobacteraceae & Roseobacteraceae \\
\hline SY255 & Chaetoceros calcitrans & HE589564 & & Rhodobacteraceae & Roseobacteraceae \\
\hline SY118 & Nannochloris sp & HE995402 & & Hyphomonadaceae & Hyphomonas sp \\
\hline SY145 & Chaetoceros sp & HE589549 & & Hyphomonadaceae & Algimonas sp. \\
\hline SY196 & Chaetoceros sp & HE589559 & & Hyphomonadaceae & Algimonas sp. \\
\hline SY007 & Phaeodactylum & HE589567 & \multirow{12}{*}{ Gammaproteobacteria } & Alteromonadaceae & Alteromonas sp. \\
\hline SY102 & Odontella aurita & HE589577 & & Pseudoalteromonadaceae & Pseudoalteromonas sp. \\
\hline SY182 & Nannochloris sp & HE995404 & & Pseudomonadaceae & Pseudomonas sp \\
\hline SY003 & Odontella aurita & HE589565 & & Halomonadaceae & Halomonas sp. \\
\hline SY213 & Emiliania huxleyi & HE589587 & & Halomonadaceae & Halomonas sp. \\
\hline SY135 & Chaetoceros minus & HE589581 & & Alteromonadaceae & Marinobacter alkaliphilus \\
\hline SY171 & Chaetoceros minus & HE589584 & & Alteromonadaceae & Marinobacter alkaliphilus \\
\hline SY185 & Chaetoceros minus & HE589585 & & Alteromonadaceae & Marinobacter alkaliphilus \\
\hline SY032 & Odontella aurita & HE589572 & & Alteromonadaceae & Marinobacter sp. \\
\hline SY089 & Skeletonema marinoi & HE589576 & & Alteromonadaceae & Marinobacter sp. \\
\hline SY106 & Chaetoceros pumilum & HE589578 & & Alteromonadaceae & Marinobacter sp. \\
\hline SY260 & Thalassiosira $s p$ & HE589591 & & Alteromonadaceae & Marinobacter sp. \\
\hline
\end{tabular}


Table 2 : ANOVA table resulting from the factorial design approach used for comparison of $\mathrm{OD}_{680}$ to fluorescence as proxy for microalgal population in mixed culture. Significant $\mathrm{p}$ values $(\alpha=0.01)$ are given in bold. $(+)$ and $(-)$ symbols depict positive or negative effects for the corresponding factor. $A$ stands for microalgae concentration, $B$ for bacterial concentration, $A A$ and $B B$ for the corresponding quadratic effects and $A B$ for interaction.

\begin{tabular}{lcccccc}
\hline & $\mathrm{A}$ & $\mathrm{B}$ & $\mathrm{AA}$ & $\mathrm{BB}$ & $\mathrm{AB}$ & $\mathrm{R}^{2}(\%)$ \\
\hline $\mathrm{OD}_{680}$ & $\mathbf{0 . 0 0 0 3}(+)$ & $\mathbf{0 . 0 0 0 0}(+)$ & $0.4271(-)$ & $0.1432(-)$ & $0.0985(+)$ & 99.88 \\
& & & & & & \\
fluorescence & $\mathbf{0 . 0 0 0 6 ( + )}$ & $0.0277(-)$ & $0.0223(-)$ & $0.9183(-)$ & $0.1790(-)$ & 99.62 \\
\hline
\end{tabular}

Table 3 : shape, quotas and contribution for bacteria to particulate $\mathrm{C}$ and $\mathrm{N}$ recovered on GF/C filters. For each column, the values presented are median and interquartile range (IQR) in brackets.

\begin{tabular}{|c|c|c|c|c|}
\hline & Xenic & SY003 & SY007 & SY244 \\
\hline Shape & cocci & cocci & bacilli & bacilli \\
\hline $\mathrm{Q}_{\mathrm{C}}\left(\mathrm{fmol} \mathrm{C} \cdot \mathrm{cell}^{-1}\right)$ & $6.4 *(0.3)$ & $6.4(0.3)$ & $27.7(4.7)$ & $18.3(0.3)$ \\
\hline $\mathrm{Q}_{\mathrm{N}}\left(\mathrm{fmol} \mathrm{N} \cdot \mathrm{cell}^{-1}\right)$ & $1.3^{*}(0.1)$ & $1.3(0.1)$ & $5.1(0.9)$ & $3.6(0.1)$ \\
\hline$\%$ of particulate $\mathrm{C}$ & $0.05(0.05)$ & $9.6(0.2)$ & $3.6(1.2)$ & $0.41(0.2)$ \\
\hline$\%$ of particulate $\mathrm{N}$ & $0.2(0.2)$ & $33.8(0.9)$ & $14.6(5.1)$ & $2.1(0.81)$ \\
\hline
\end{tabular}

* on the basis of microscopic observation, same quotas were considered for bacteria in the xenic cultures and for SY003 
Table 4 : physiological results for Dunaliella $s p$. in experiment 2, including growth parameters $\left(\mu_{\max }\right.$ and $\left.\Delta X_{\max }\right)$ computed on a per carbon basis, cell biovolume, carbon quota, computed $\mathrm{C}: \mathrm{N}$ ratio, and nitrogen incorporation. Dunaliella sp. was cultivated in different conditions : xenic and axenic strains and associated with the selected bacteria SY003, SY007 and SY244. For each column, the values presented are median and interquartile range (IQR) in brackets. Values with the same superscript letters are not statistically different (Kruskal Wallis test; $\alpha=5 \%$ ).

\begin{tabular}{lcccccc}
\hline & Axenic & SY003 & SY007 & SY244 & Xenic & P value \\
\hline$\mu_{\max }\left(\mathrm{d}^{-1}\right)$ & $0.36^{\mathrm{a}}(0.05)$ & $0.26^{\mathrm{b}}(0.05)$ & $0.33^{\mathrm{a}}(0.01)$ & $0.27^{\mathrm{b}}(0.01)$ & $0.22^{\mathrm{b}}(0.01)$ & $0.018(\mathrm{n}=3)$ \\
$\Delta X_{\max }(\mathrm{mM})$ & $8.0^{\mathrm{a}}(0.5)$ & $5.4^{\mathrm{b}}(0.5)$ & $10.5^{\mathrm{c}}(0.3)$ & $10.8^{\mathrm{c}}(0.5)$ & $6.0^{\mathrm{d}}(0.3)$ & $2.210^{-5}(\mathrm{n}=6)$ \\
Cell biovolume $\left(\mu \mathrm{m}^{3}\right)$ & $384^{\mathrm{a}}(15)$ & $350^{\mathrm{b}}(15)$ & $337^{\mathrm{c}}(8)$ & $411^{\mathrm{d}}(21)$ & $285^{\mathrm{e}}(16)$ & $3.810^{-7}(\mathrm{n}=9)$ \\
$\mathrm{Q}_{\mathrm{C}}\left(\right.$ pmol C.cell $\left.{ }^{-1}\right)$ & $20.6^{\mathrm{a}}(0.6)$ & $19.6^{\mathrm{b}}(0.6)$ & $17.2^{\mathrm{c}}(0.9)$ & $22.4^{\mathrm{d}}(1.0)$ & $14.7^{\mathrm{e}}(0.9)$ & $3.610^{-8}(\mathrm{n}=9)$ \\
$\mathrm{C}: \mathrm{N}$ & $29.6^{\mathrm{a}}(1.4)$ & $24.4^{\mathrm{b}}(1.3)$ & $24.1^{\mathrm{bc}}(2.4)$ & $25.6^{\mathrm{d}}(0.5)$ & $22.8^{\mathrm{c}}(1.7)$ & $8.910^{-7}(\mathrm{n}=9)$ \\
$\mathrm{N}$ incorporation $(\%)$ & $26^{\mathrm{a}}(9)$ & $19^{\mathrm{b}}(2)$ & $56^{\mathrm{c}}(3)$ & $56^{\mathrm{c}}(4)$ & $34^{\mathrm{d}}(5)$ & $6.9110^{-7}(\mathrm{n}=9)$ \\
\hline
\end{tabular}




\section{Figures}

Figure 1 : microalgal and bacterial concentrations tested in mixed suspensions during the central composite experiments. Light grey dots represent experiments for the 2-level factorial design. Dark grey dots represent experiments at the center of the experimental domain, used to compute experimental variance. Distance between star-points (white dots) and the center of the experimental domain was calculated using the axial distance $\alpha=1.414$. Measurements for $\mathrm{DO}_{680}$ and in-vivo $\mathrm{Chl}$ a fluorescence were made for the 11 experiments.

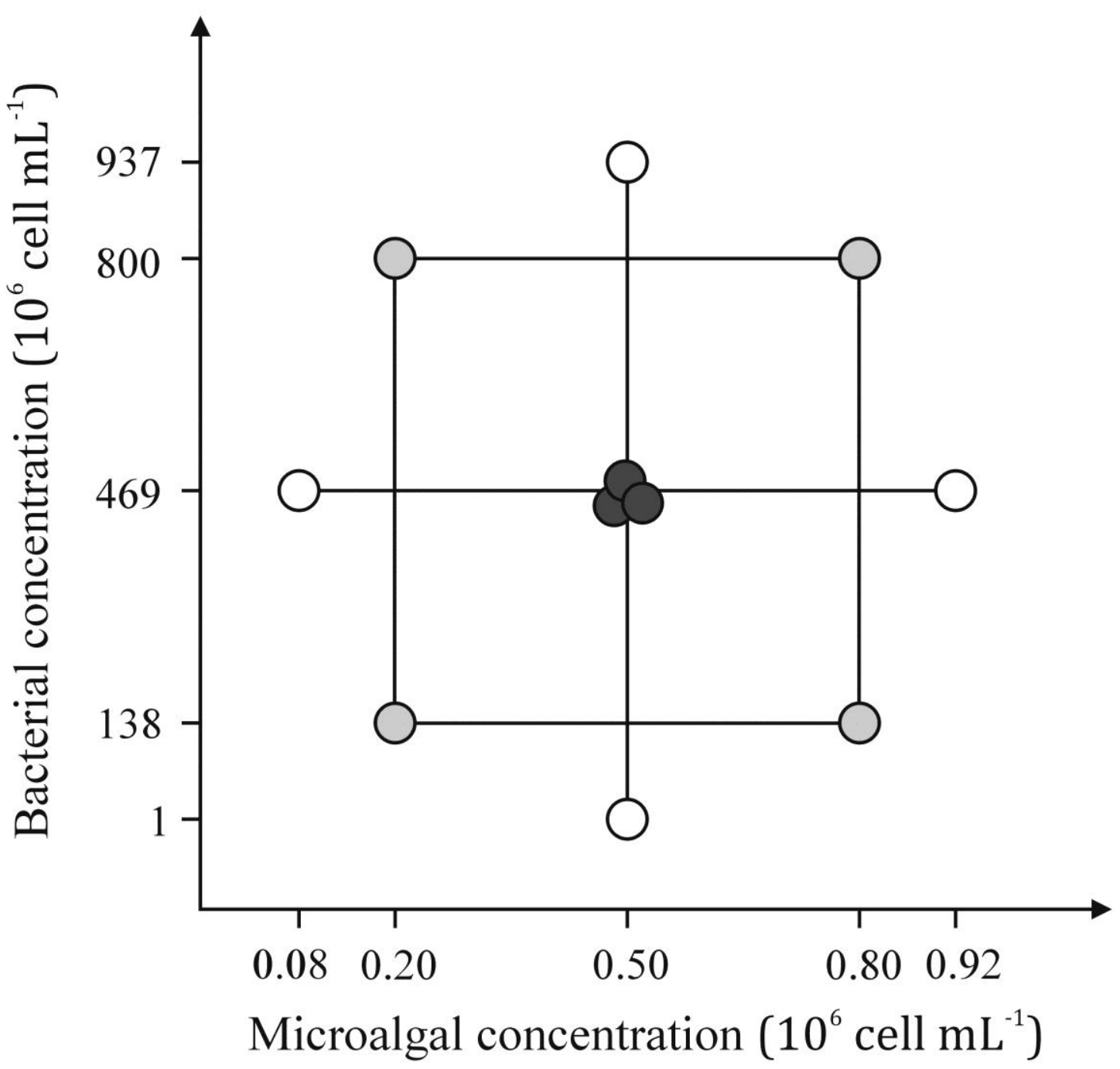


Figure 2 : maximal growth rate $\left(\mu_{\max }\right)$ for Dunaliella sp. SAG 19.3, calculated in the highthroughput experiment (experiment 1) for axenic, xenic or mixed cultures with different bacterial strains assayed individually. For each culture, raw data for the three replicates are connected by a vertical line to facilitate reading. Reference numbers in the collection are given on the $\mathrm{X}$-axis.

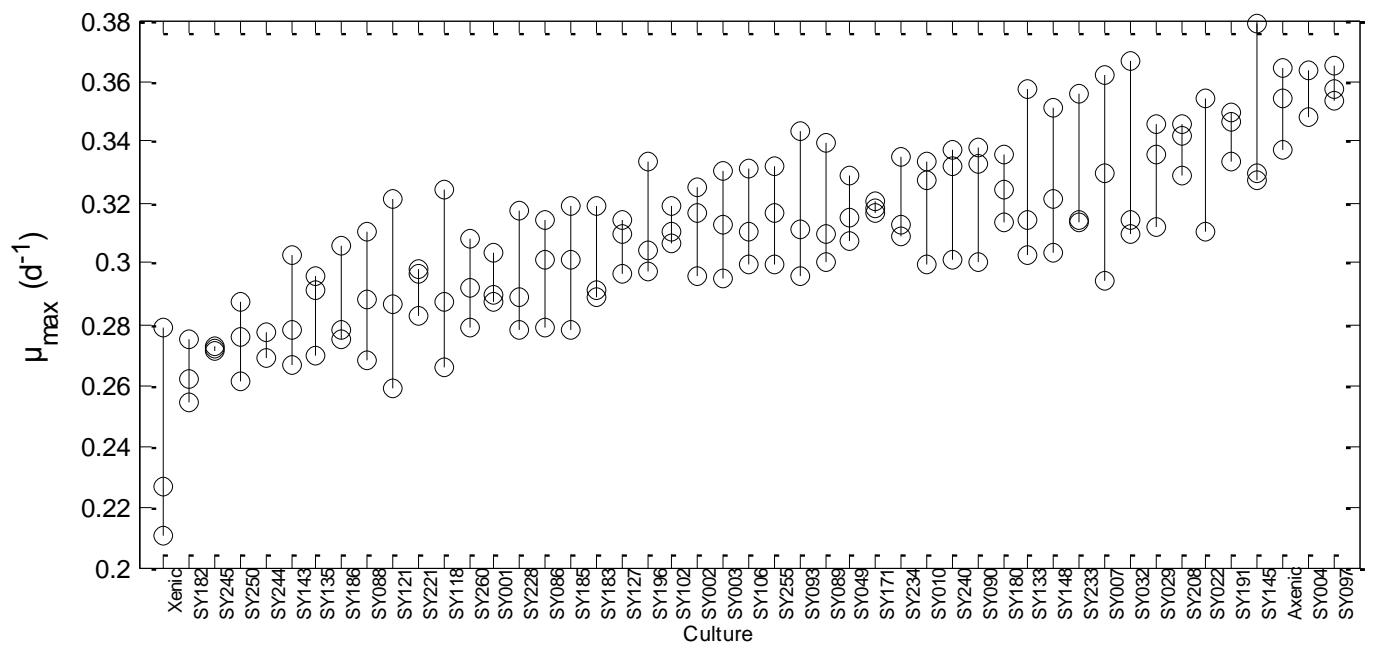

Figure 3: maximal biomass increase $\left(\Delta X_{\max }\right)$ for Dunaliella sp. SAG 19.3 estimated in the high-throughput experiment (experiment 1 ) for axenic, xenic or mixed cultures with different bacterial strains assayed individually. For each culture, raw data for the three replicates are connected by a vertical line to facilitate reading. Reference numbers in the collection are given on the $\mathrm{X}$-axis.

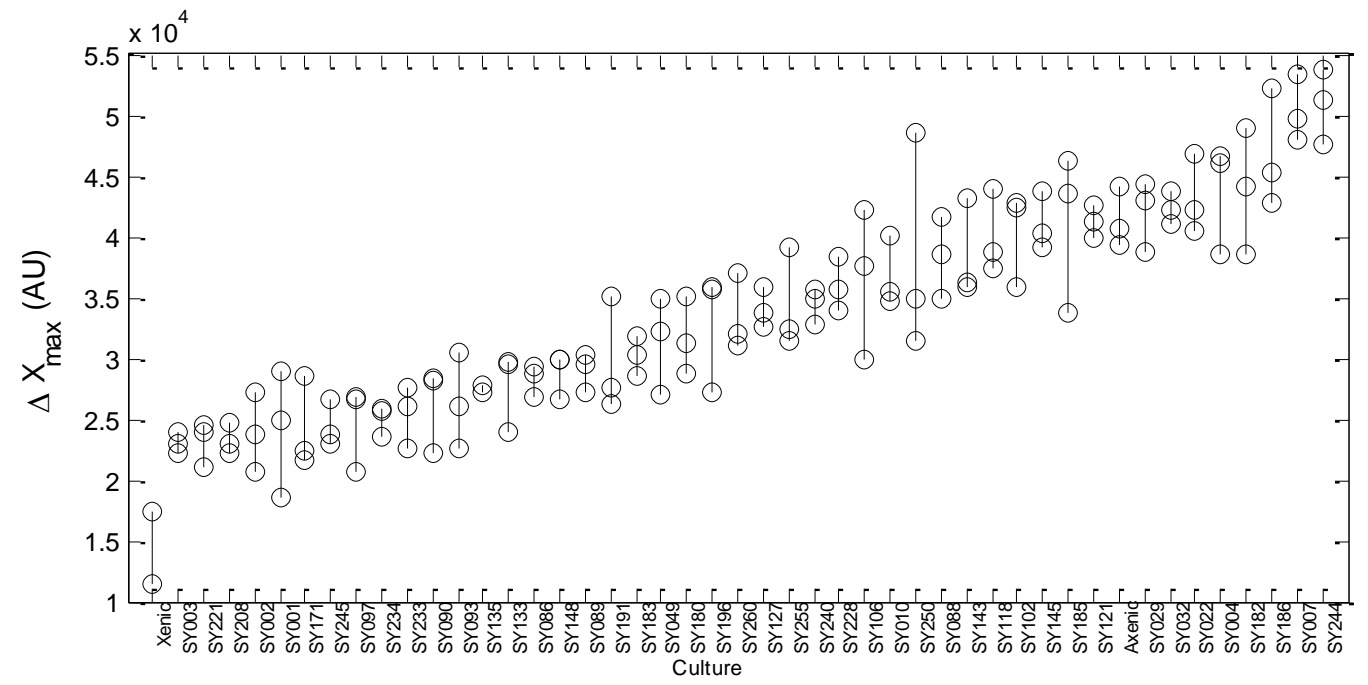


Figure 4: RAPD-PCR profiles for isolates from flask mixed cultures SY003, SY007 and SY244 (experiment 2) compared with the relevant SY003, SY007 and SY244 controls from the collection. Results were obtained with the two primers RAPD 1 and RAPD 4. Two bacteria colonies ( $\mathrm{C} 1$ and $\mathrm{C} 2$ ) were analysed for the three replicated flasks (F1, F2 and F3).

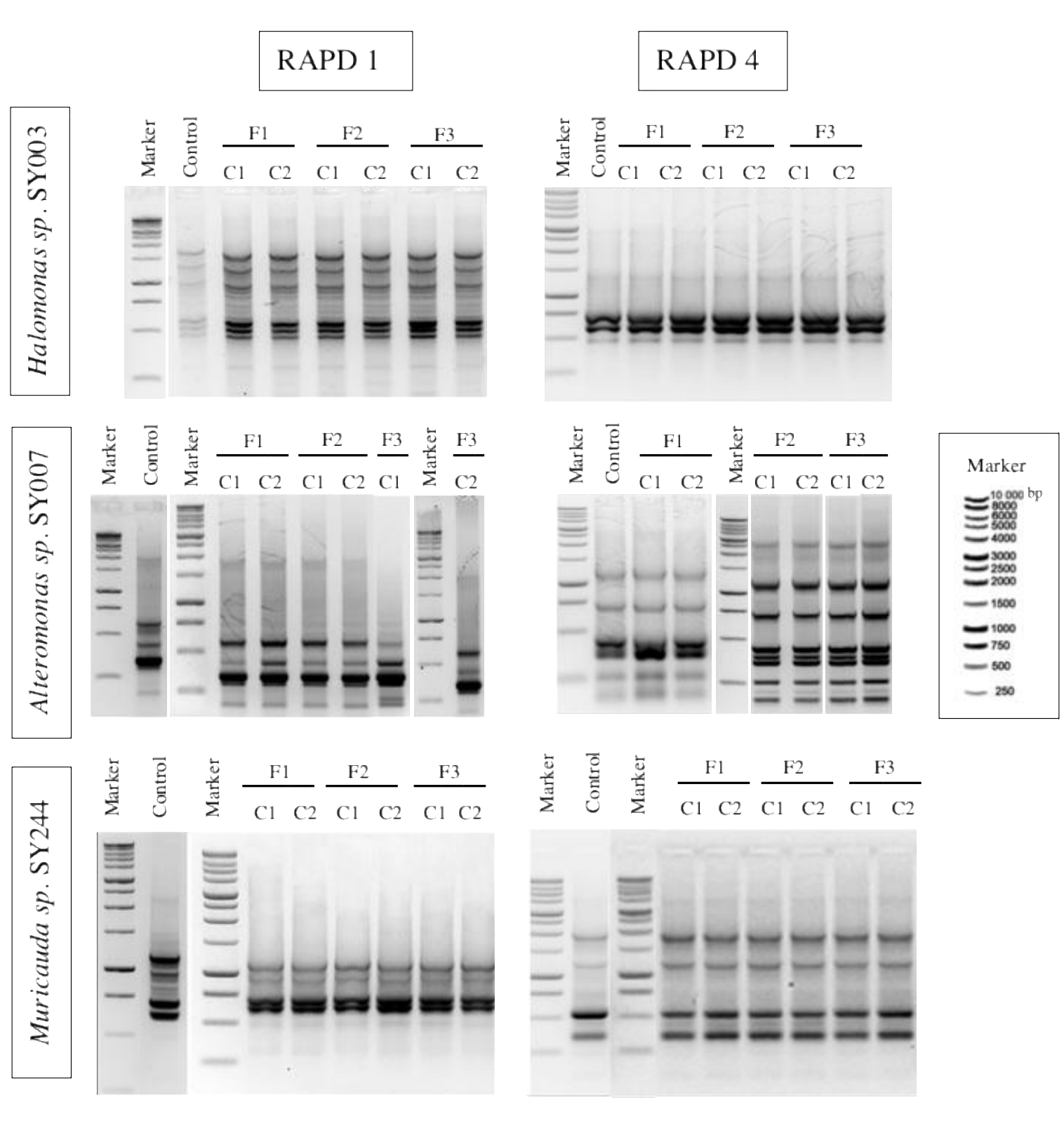


Figure 5 : A) Particulate carbon growth curves in flask cultures (experiment 2) for axenic, xenic strains and mixed cultures (SY003, SY007 and SY244). B) Bacterial concentration in mixed culures at the beginning of the experiment and after 5 and 10 days of culture.
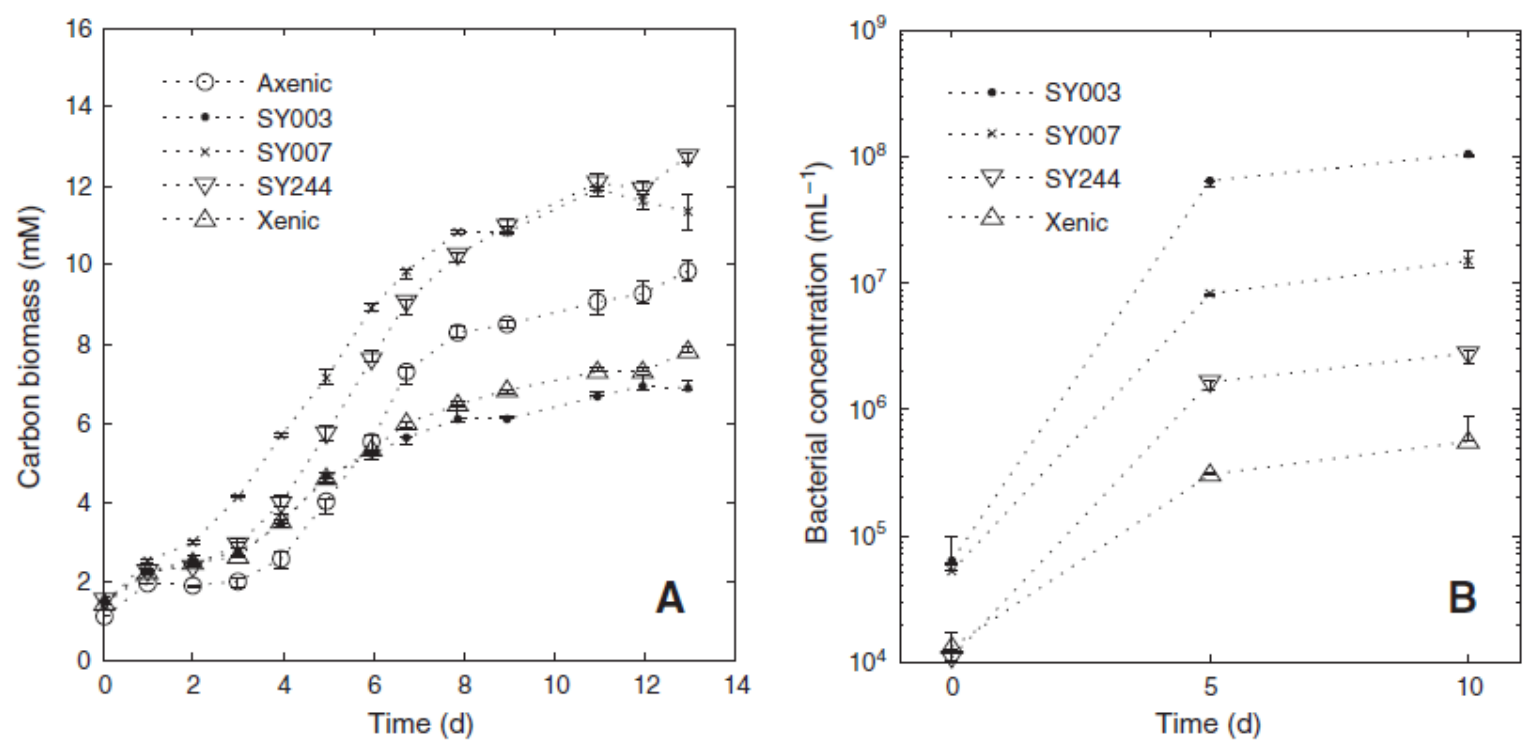